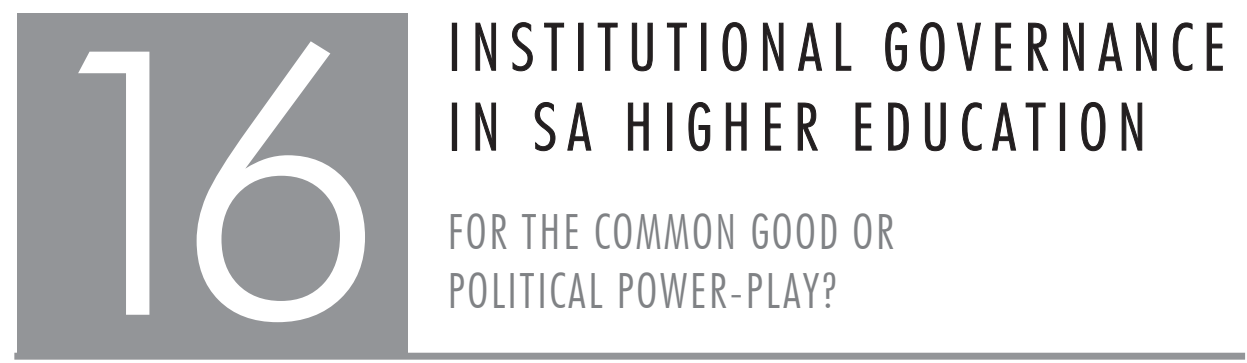

\title{
Magda Fourie
}

\section{ABSTRACT}

This chapter explores the role of institutional governance against the background of the nature of the university as an organisation, and the changing context in which universities currently operate. Three 'conventional' models of institutional governance are discussed, and more recent developments in this regard are investigated. She concludes with some guiding principles for effective institutional governance in a contested and changing university context.

\section{INTRODUCTION: THE NATURE OF THE UNIVERSITY AS ORGANISATION}

Universities, being complex organisations, can be examined at distinctly different levels:

- the inter-organisational or systems level that portrays the relationships among different institutions in a region or country, and particularly the relationship between institutions and government, institutions and society and institutions and the market;

- the organisational level that studies the institution as an organisation, attempts to understand its functions, structure and dynamics, and particularly the relationships between different actors in the organisation;

- the intra-organisational level that focuses on the individual units of the organisation, how they are organised and managed and how they interact.

The focus of this contribution is the second level, namely the university as organisation and, more specifically, how it is governed at the institutional level. Admittedly, the 


\section{PART FIVE - STRUCTURES AND GOVERNANCE}

national policy environment greatly influences institutional governance. South Africa is not the only country where regulatory measures by the government have increased over the past 10 years. Rhoades (1992:1380) points out that "the exercise of state level bureaucratic as well as political authority over higher education organizations is on the rise. From one country to the next, the 1970s and 1980s have seen external as well as internal challenges to the structure and function of academic institutions". The exercise of authority takes various forms, from attempts to reform the curriculum (cf. the SA Higher Education Qualifications Framework), restructuring the higher education system (cf. the SA National Plan for Higher Education), to increasing the accountability of academics (cf. the programme accreditation and institutional audit system of the SA Higher Education Quality Committee).

Tapper and Palfreyman (1998:153) cite the example of the Research Assessment Exercises (RAEs) of the British government that inexorably shifted the balance between teaching and research within universities, resulting in (possibly unintended) changes in institutional governance. Similarly, Harman and Treadgold (2007) posit that Australian higher education has in recent years experienced much more direct government intervention than in the past.

Similarly the power and perceptions of power of units inside the institution have an effect on how the institution is governed and managed. One example would be the restructuring of institutional governance bodies in order to include a broader range of stakeholders in decision making. Rhoades (1992:1380-1381) describes the situation in Western Europe as follows:

In some cases this meant creating or expanding the power of university councils that had representatives from lay community. Throughout Western Europe what it meant was democratization or participation in the form of creating corporatist arrangements in which a certain proportional representation was accorded various groups. The proportion of students, different levels of faculty, and other groups varied from one country to the next, as did the types and levels (e.g. department, faculty, university) of the corporatist councils, conferences or whatever. But the form of politics followed the corporatist forms that mark European political institutions. Moreover, in a sense these various governing bodies introduced a considerable measure of bureaucratization into campus governance, of formal mechanisms and chains of command that decision making and decision makers had to go through.

Governance of universities is quite different from this function in other service institutions like schools, churches or hospitals. Also, universities are governed very differently from 
businesses or other institutions in the corporate world. An understanding of governance of higher education therefore necessitates a basic understanding of the nature of the university, because the governance and management structures and processes are very specific to and typical of universities.

Even though universities possess characteristics common to most forms of organisation, there are fundamental differences between universities and other organisations in society. Universities are not, for example, guided by instrumental rationality towards clear, welldefined goals. Lockwood (1985) explains the uniqueness of the university in terms of the pluralistic nature of its essence, and argues that universities function simultaneously as organisations, communities and institutions. The distinguishing characteristics that set universities apart from other organisations include the following:

- Universities are loosely coupled systems in which the different divisions have but tenuous links between them and with the organisation as a whole.

- Universities are often described as professional bureaucracies in which the academics are professionals with relatively large measures of autonomy. Academics often have stronger allegiances to their subject disciplines and the disciplinary community than to the university.

- Universities have diffuse missions and vague, ambiguous goals, and they must devise decision-making processes to contend with a high degree of uncertainty and conflict. Even though they are described as knowledge organisations which have the primary purposes of producing knowledge, disseminating knowledge and applying knowledge, how these purposes are being pursued and the value and importance of the different purposes can differ substantially from one institution to another. Furthermore, universities are traditionally non-profit service organisations that are in many cases today forced to become entrepreneurial.

Clearly then universities are among the most complex forms of organisation, and the level of complexity increases as the size of the institution grows and the scope of its functions expands, resulting in the need to add specialised and differentiated units. Hartman and Scott (1990:2) maintain that the very nature of the work of higher education (producing, conserving and distributing knowledge) contributes to this complexity, because of the "fundamental tensions between the need to create conditions that foster the development of knowledge in its various divisions and the demands of managing the institution as a coherent entity". It can be expected that this complexity will be reflected in the challenges faced by the structures and processes of governance. It can also be expected that these challenges will be exacerbated 


\section{PART FIVE • STRUCTURES AND GOVERNANCE}

in a context of change. Kaplan (2006:213) makes the point that understanding the behaviour of higher education institutions as organisations is of increasing importance "in an economy in which knowledge work and the production of knowledge are increasingly the drivers of economic advancement and growth".

\section{INSTITUTIONAL GOVERNANCE: WHAT ARE WE TALKING ABOUT?}

Institutional governance is based on the principles of pluralistic representation, joint effort, extensive communication, and shared but differentiated participation by the different constituents (Kauffman 1993:225). In general terms governance is about power and authority - the distribution of power and authority within an organisation, the structures and relationships by means of which the power and authority are obtained and the processes through which the power and authority are used. This power and authority is employed by different actors in governance structures and processes. In these structures and processes sets of explicit and implicit rules determine actors' behaviour: "These rules indicate who, from which position, and with what authority, may command whom, and impose sanctions if the rules and commands are not complied with" (Frederiks et al. 1994:98).

From the above it can be gathered that institutional governance pertains particularly to the decision-making process within the institution (Atwell 1996:13). It relates to the power and influence of the various stakeholders like academic and administrative staff, students and the community and to the ways in which an organisation divides its labour into distinct tasks and then achieves coordination among them; in other words, it can be regarded as a system of agreements among the organisational actors with respect to the performance of activities directed towards a set of common goals (Binsbergen et al. 1994:220; Balderston 1995:55).

Like Atwell's, Corson's (1976:9) definition of governance focuses on decision making:

By the term 'governance' I mean the processes by which decisions are made, who participates in these processes, the structure that relates those individuals, the effort that is made to see to it that decisions once made are carried out, and the processes used to evaluate the results that are achieved.

Peterson (1986:1) agrees that governance at the institutional level refers to the processes and structures through which individuals and groups participate in and influence decision processes in higher education, and points out that it is concerned with broad institutional rather than internal organisational issues. Traditionally governance pays particular attention to defining and differentiating the appropriate 
roles of constituencies and major decision structures and processes. The focus is on relationships: "The term 'governance' refers to the interrelationship among major roles, structures, and patterns of authority in the decision-making process in academic organizations" (Peterson 1986:3).

Governance cannot be studied or discussed in isolation from the related functions of management and leadership. Governance, management and leadership are simultaneously bound together and differentiated by the notion of decisions: governance implies both the structures and the processes of decision making, management denotes the structures and processes for implementing or executing the decisions taken by governance structures, whereas leadership refers to the structures (positions, offices and formal roles) and processes through which individuals seek to influence decisions (Peterson 1986:3, 4). It can be concluded, therefore, that although it is possible to draw a distinction between management and governance in higher education institutions, it is never simple to do so and the relationship between governance and management is one fraught with complexity. This complexity is intensified when pressures on institutions mount or where institutions operate in a climate of change or uncertainty.

Following from the premise that governance is about decision making, one should also interrogate what decisions are taken on. In universities governance involves decisions about the purpose and mission of the institution, and about the policies, programmes and resources required to achieve the mission. In addition, governance also concerns academic policies and affairs.

The above conceptualisation of governance more or less describes the 'traditional' definition of governance. Important and critical questions would be: What happens to governance of universities in times of change. Can and do governing bodies instigate or promote change and transformation? How does change impact on the relationships between difference governance structures? The effect of change on the university as an organisation as theorised by Barnett (2000) and applied to South African higher education is discussed below.

\section{UNDERSTANDING THE UNIVERSITY IN TIMES OF CHANGE}

During times of organisational reform and transformation, universities are particularly fragile. To describe this state of fragility, Barnett (2000) uses four concepts that he claims are key to understanding the post-modern university: uncertainty, unpredictability, challengeability and contestability. Sociologically, these factors relate to the conditions of the world, but also to the state of being in which the university finds itself today. 


\section{PART FIVE - STRUCTURES AND GOVERNANCE}

Barnett (2000:66) points out that "[i]t is an age of uncertainty and unpredictability because it has become an age of challengeability and contestability".

Although in developing countries universities are to a larger or lesser extent prone to similar forces for change as those experienced by institutions in developed countries (cf. Green and Hayward 1998), , historical, political and economic factors cause these institutions to demonstrate subtle but important differences in nuances as far as the above-mentioned four concepts are concerned.

Barnett (2000:65) declares that "[u]ncertainty is that state of being in which one cannot be certain. Uncertainty is partly cognitive, but it is primarily experiential: it is an expression of one's mode of being in the world." At present, universities in South Africa are uncertain about many things: what government, the public and employers expect from them, such as what their role in the new South Africa should be, how they can play that role effectively, how they should be meeting the needs of the new generation of students, how they should be coping with the demands of globalisation, and what the effects of the global economic crisis on them would be. Since universities have traditionally had vague objectives and diffuse missions, further intensification of uncertainty in the university's context may contribute to growing dissent between actors in institutional governance and management. It is conceivable that less clarity about the university's 'state of being' may lead to growing disparities in what the council, senate and management believe the institution should stand for.

The world of South African universities has also become highly unpredictable. Moving from an isolated, divided system in the apartheid era towards a single coordinated system with higher levels of participation and responsiveness, within a developing economy and poor quality of primary and secondary education, South African higher education faces a multitude of challenges. Not only have government subsidies for universities been declining constantly, but unpaid student fees and rising expenses have brought some institutions to the brink of financial disaster. The effects of the meltdown in the global economy will certainly be felt by South African universities in decreasing third-stream income from research contracts and foundations, and in larger numbers of students who are unable to meet their financial obligations. Such conditions of unpredictability further exacerbate the complexities of planning, policy setting and decision making, thus impacting negatively on governance and management activities.

According to Barnett (2000:65), challengeability describes a state of affairs in which the assumptions on which we depended, even though we were hardly aware of them, 
are revealed and found inadequate. Such assumptions relate to both the way that universities have traditionally organised knowledge and how they have traditionally organised themselves. In South Africa the traditional organisation of knowledge into qualifications along disciplinary lines is fast being replaced by inter- and multidisciplinary programmes of learning. Furthermore, the typical organisational structure of departments, which are housed in faculties, is being changed to suit the programmebased approach. This has led in some institutions to the development of a matrix organisational structure with departments on the one axis and programmes on the other. Other examples are those of particularly merged institutions which collapsed former academic departments into schools, and are increasingly moving towards multi-disciplinary, inter-disciplinary and trans-disciplinary programmes and research projects. The implications of such decisions for the composition and role of academic governance structures such as faculty boards and Senate are far-reaching, to name one example.

Barnett's theory (2000) furthermore argues that contestability is that state of affairs in which a proposition or framework might be subjected to the counter-punch of a rival proposition or framework. One example of contestability relates to the core business of universities. A university qualification has traditionally been a much sought after academic achievement. This is borne out by the rapid and ongoing massification of higher education worldwide - the majority of the population still seems to believe firmly in the value of education and training, also at higher levels. The assumption on which universities thus depended was that they had something worthwhile to offer, that this was valued and that they would therefore be highly regarded in and by society. In South Africa, however, this assumption has been challenged by the absence of the expected massification of higher education. Even though there has been a steady increase in participation rates of blacks in particular, the actual growth in the system has been much slower and smaller than expected. Slogans like 'Liberation before education', and pronouncements by public figures that 'you don't need education to be a leader' (after the election of Mr Jacob Zuma as President) have added to a disregard of the traditional inherent worth or value of higher education.

In applying Barnett's theory to South African higher education, I have illustrated above that our universities are prone to the uncertainty, unpredictability, challengeability and contestability of rapidly and radically changing internal and external environments. Coughlan (2006:582) makes the point that higher education has never been static, and that it has always been subject to change; yet, the challenges faced by higher education 


\section{PART FIVE - STRUCTURES AND GOVERNANCE}

in a transforming South African society are even "more intense and extensive" than ever before.

Against this background the question posed by Tapper and Palfreyman (1998:143) is of importance: "If universities are functioning in a radically changed environment which requires them to adopt both different purposes and to restructure their ties to state and society, does it not then follow that they need to govern themselves differently?" This is echoed by Talburt (2005:459) who cites a line of thinking that the current 'crisis' of higher education requires the reform of governance "to enable efficient decision making so that universities may respond effectively to changing 'environments'". This calls for an exploration of the 'traditional' models of institutional governance.

\section{MODELS OF INSTITUTIONAL GOVERNANCE}

For many scholars the classic model of governance is that of the autonomous, selfgoverning institution. However, Rhoades (1992) points out that all systems consist of a mix of academic (collegial), political and bureaucratic types of authority. These 'standard' models of governance "invoke notions of community, position, and expertisebased authority, and pluralistic politics, all related to legitimate authority" (Rhoades 1992:1377). Interrogating these models of institutional governance, and exploring the ways and reasons for their changing, might shed some light on the current state of institutional governance.

In his discussion of governance models, Rhoades (1992:1377) typifies the collegial model of academic governance as one that "emphasizes non-hierarchical, cooperative decision making and the significance of faculty self determination. Various campus constituencies are knit together by common interests and by a sense of academic community that legitimizes the concerns of these parties." The two most important principles of the collegial model are firstly, the idea of a community of scholars in which decisions are a matter of consensus, and secondly, the idea of professional authority that is based on competence rather than on position. This model reflects common interest, what Birnbaum (1988:85) calls "sharing power and values in a community of equals". Tapper and Palfreyman (1998:145) believe that "integral to the idea of collegiality is that nothing can be achieved unless it has the formal blessing of the collective membership".

Collegiality has been presented as the traditional view of higher education governance in which members' loyalty and commitment bind them to organisational goals, leading to consensus decision making. Yet, Rhoades (1992:1379) admits that "in 
the post-1960s era one would be hard pressed to find evidence in the literature of a collegial model of governance in operation", and points out that the expansion and assertion of bureaucratic/managerial authority has become more evident. In their study of institutional governance, Tapper and Palfreyman (1998:157) found that there is considerable evidence to suggest that collegial forms of governance in higher education are becoming less influential and less used.

Max Weber's bureaucratic model suggests in essence that bureaucracies are networks of social groups dedicated to limited goals and organised for maximum efficiency (Baldridge et al. 1986:16). A bureaucratic process model means that routines and procedures are used to resolve decisions.

In order to accommodate professional organisations like higher education institutions in the bureaucratic model, Mintzberg developed the model of the professional bureaucracy in which the professional and the bureaucratic co-exist. In the professional bureaucracy allegiance is to the profession or discipline rather than to the organisation and adherence to professional values rather than to organisational goals binds members together; the "existence of professional values, which guide, motivate, and control members, makes this 'self-government' possible" (Hardy 1990:395). Another characteristic of the professional bureaucracy is the decentralisation of power and responsibility which in itself creates certain tensions. Bess (2006:532) believes that universities "as professional bureaucracies must live with both the structural conflict engendered by democratic decision making and the functional ambiguities of mixed democratic and bureaucratic systems".

Most higher education institutions are composed of large numbers of individuals and groups that in some ways operate autonomously, but in other ways remain interdependent. It is this interdependence that often gives rise to political behaviour. Politics and power only become relevant when individuals or institutions must rely on others for some necessary resources, in other words when interdependence forces them to become concerned about or interested in the activities of others (Birnbaum 1988:132).

The political model, developed by Baldridge in the 1970s, assumes that complex organisations like higher education institutions can be studied as miniature political systems. The model focuses on policy-forming processes, because major policies commit an organisation to definite goals and set the strategies for reaching those goals (Baldridge et al. 1986:20). These authors postulate that governance is less about professional authority than about "a process of political negotiation, lobbying, and 


\section{PART FIVE - STRUCTURES AND GOVERNANCE}

coalition formation in which leaders, acting as members of state, strategize, mediate, and fashion compromises" (Baldridge et al. 1977, cited by Rhoades 1992:1377).

Although the political model encapsulates self-interest, and emphasises dissensus and conflict among interest groups, institutions which display these characteristics are not constantly in turmoil and a state of instability. Birnbaum $(1988: 136,137)$ explains why:

- Organizations tend to develop continuing and quasi-stable dominant coalitions whose established power serves to inhibit overt conflict.

- Individuals belong to more than one group and they participate in many political processes, each of which involves different people; therefore deep cleavages dividing major groups on many issues are unlikely.

- Most people in political communities are indifferent and not concerned about most issues most of the time.

- Disruptive conflict is inhibited, because power in higher education tends to be issue specific (see also Baldridge et al. 1986:20; Hardy 1990:398).

Most scholars would agree that in practice institutional governance shows characteristics of a variety of models. Furthermore, new concerns that pose altogether different challenges for higher education managers and leaders have arisen. The preoccupation with money and management shares centre stage with issues of quality, institutional effectiveness, and some very fundamental questions about whom higher education is serving and how well it is being done. Also, leading more heterogeneous institutions requires different skills - as staff and student bodies change, so must institutions and their leaders. Even at the traditional collegial institutions of Oxford and Cambridge central administration has become much more interventionist "requiring, for example, faculties and departments to justify costs which seem exceptionally inflated or how they intend to rectify apparent failings which have been identified by outside parties. It may be too soon, and too bold, to talk of central planning but clearly there is a more pervasive managerial ethos" (Tapper and Palfreyman 1998:158) The higher education environment is also marked by intense competition among institutions - for students, for research grants, for private sector funding and for research and development contracts, amongst others, leading to entrepreneurial initiatives by academic leaders. This raises questions about matters such as academic integrity, the nature of academic hierarchy, and the distribution of resources (Tapper and Palfreyman 1998). A traditional model of collegial governance can thus be threatened as much by the market as by the state. Clark, for example (cited by Rhoades 1992:1378), distinguishes at the 
institutional level only between trustee authority and bureaucratic authority, and for Clark bureaucracy is synonymous with managerialism, in other words, with top-down control.

International and local evidence suggests two things: firstly, that a hybrid model of higher education governance is developing, one that is moving away from collegiality, that is neither purely bureaucratic nor purely political, but one that tries to respond to primarily external pressures through a sort of corporate or managerialist model; and secondly, that there is a growing uneasiness with the notable increase in the power of administrators and other officials as distinct from the authority of the professoriate in the governance and management of academic institutions.

It seems appropriate therefore to return to the question posed earlier: If universities have to function within changed environments, forcing them to adapt their purposes, structures and processes, should institutional governance not change as well?

\section{CHANGES IN SOUTH AFRICAN HIGHER EDUCATION}

Some of the changes in South African higher education have already been alluded to. A study by the Centre for Higher Education Transformation (CHET 2000) shows that vice-chancellors of South African universities regard the issue of financial stability as the most important challenge facing their institutions. As pointed out above, in a context where there is stiff competition for scarce resources (whether at a systems or an institutional level) it seems as if collegial models of governance make way for more political or corporate models.

In the recent past several media reports pointed to growing levels of tension or even conflict between different actors (individuals and groups) in institutional governance. One such example is that of the University of KwaZulu-Natal where the council in December 2008 appointed an internal panel to investigate complaints of lack of academic freedom at the university. Staff members reportedly said that there was widespread dissatisfaction with the university's management style (Mail \& Guardian 13-16 March 2009:6) and that academics were becoming increasingly dissatisfied with this model. David Coldwell (27 November 2008) writes in the Mail \& Guardian Online:

The call of managerial efficiency has taken precedence and has all but destroyed the fragile infrastructure that made universities distinctive. Job descriptions, performance appraisals, managerial procedures and processes have sprung up and flooded the campuses where none were required before. As a general 


\section{PART FIVE • STRUCTURES AND GOVERNANCE}

rule, these corporatist manifestations have had a severely debilitating effect on academic morale. Caught in a pincer movement between the two relentless forces of massification and managerialism, academic has wilted. The need, on the one hand, to attend to matters of financial and managerial efficiency, while on the other being confronted with the requirement of accommodating increasing student numbers, more teaching, marking and administration, while having fewer resources to fall back on and less time to achieve particular objectives, means that academics are being managerially monitored and controlled as never before.

Other examples include those of the University of the Free State where in 2008 a number of factors, amongst others, dissensus between council and management, led to the stepping down of the vice-chancellor, and Stellenbosch University where differences between some council members and management resulted in distasteful mudslinging in the media.

In addition to this somewhat anecdotal evidence, a number of recent studies provide evidence of a lack of trust among actors and dissatisfaction with governance arrangements. In a study done in 2007 by Wolhuter, Higgs and Higgs, academics were asked to score their influence in shaping key academic policies at departmental, faculty, and institution level. They had to indicate their response on a four-point Likert scale, with 1 signifying 'very influential', 2 'somewhat influential', 3 'a little influential' and 4 'not at all influential'.

The mean responses were as follows:

- departmental level: 2.12

- faculty level: 2.65

- institutional level: 3.73

Whereas academics felt that they had some influence in shaping key academic policies at departmental level and a little influence at faculty level, they had no influence in shaping such policies at institutional level (Wolhuter et al. 2007).

Johnson (2006) cites the study done by Webster and Mosoetsa (2001) on the changing nature of academic work as a consequence of managerialism in six South African universities. This study shows that academic work has become subject to more managerial control which has often resulted in a sense of loss of community and feeling of powerlessness among staff (Johnson 2006:61). Johnson followed this study with her own study among academics at the University of the Witwatersrand, which, amongst 
others, found that academics felt they had less access to information, which made it increasingly difficult for them to make informed decisions, and even when they were consulted, the consultative process seemed meaningless. Other comments pointed to changed relationships between academics and senior colleagues in managerial positions. Words used in this regard include 'mistrust' and 'bad attitude'. Respondents also believed that the university had become more managerial and corporate, and that managers seemed to have higher status and better remuneration. The most telling remark, symbolising the death of collegialism, was: "The social fabric of the department has disintegrated" (Johnson 2006:69).

According to Malcolm (quoted by Gerritsen 2008), the move towards a more managerial style of leadership has "increased stress on the governance-management nexus". A contributing factor is the complexity of today's universities that often makes it difficult for the lay members of council to understand them. This is exacerbated when council members are elected or appointed because they represent specific constituencies instead of having particular competencies in governance. Furthermore, some council members may be inclined to promote their own parochial interests (or that of their 'constituency') in council deliberations rather than fulfilling their obligation to serve the best interest of the institution as custodians.

\section{A NEW MODEL OF INSTITUTIONAL GOVERNANCE FOR SOUTH AFRICAN UNIVERSITIES?}

Although no formal large-scale studies on institutional governance in South African universities have been done lately, I believe sufficient evidence exists to conclude that current governance arrangements do not inspire confidence in some of the major stakeholders in the institution. Trakman believes that the functional values of any governance model depends on how it is applied in a particular case and that "each governance model is only as effective as those who craft it along with those who order their lives in light of it" (2008:64). Is it possible then to find a 'new' model of institutional governance for South African universities which are operating in conditions of uncertainty, unpredictability, challengeability and contestability, and if so, what should such a model be like?

When considering an appropriate institutional governance model for current South African higher education, Coughlan (2006:585) suggests a hybrid model which she calls 'managed managerialism" "that will give a modern university a fighting chance of being able to respond to the new challenges and the pace at which they are coming 


\section{PART FIVE - STRUCTURES AND GOVERNANCE}

while enjoying the trust of the academy". She goes on to say: "Managed managerialism enables universities to take on only enough of the principles of effective corporate type management to ensure that the deliberative environment that academic autonomy demands will not be under threat" (Coughlan 2006:588).

In their study on changing patterns of governance for Australian universities, Harman and Treadgold (2007) found that, like overseas universities, Australian universities too, during the 1980s and 1990s, moved away from the traditional collegial model to a model more closely aligned with business corporations. Questions about the appropriateness of the latter model for universities have prompted them to look for other options. They propose a trusteeship or trustee model, and describe the duty of a trustee as "to preserve, protect and enhance the value of assets under her/his control and deal fairly with any returns these assets may provide" (Harman and Treadgold 2007:16,17). They conclude by saying: "As a trusteeship model attempts to blend benefits from the 'corporate' model with a more community-oriented approach for the long-term benefit of the institution, it could thus be seen as a more sensible approach to governance" (Harman and Treadgold 2007:26).

It remains to be seen whether either of the models proposed above, or any other model, would provide solutions to the institutional governance challenges that South African universities are facing. I wish to conclude simply by pointing out some basic points of departure that need to be kept in mind for institutional governance to become more effective in fulfilling its purpose.

\section{CONCLUSION: FOR THE COMMON GOOD}

Firstly, the nature of the university as an organisation and the complexity of the context in which universities currently operate pre-empt the probability of clear-cut, 'neat' answers to questions or solutions to problems. Decision making in institutional governance more often than not requires the weighing of the pros and cons of different propositions, and settling for the option which will do the least harm. It is very seldom possible to find a perfect solution that will serve the best interests of the institution and satisfy all role-players. This incommensurability of higher education should be acknowledged by all actors involved in institutional governance. There should be recognition of the competing interests in governance and tolerance of those differences without endorsing divisive actions.

Secondly, it has become clear that a university can only be governed effectively if the different actors (council, management, academic staff/senate) share the same 
vision for the institution, agree on the ways and means to realise that vision, and play their respective roles appropriately. This implies that the actors should have clarity on the nature of a university, as well as an understanding of the environment in which the particular institution is operating. In the relationship between governance and management structures the rules by which players conduct themselves need to be clear and accepted by both parties.

Thirdly, a sense of trust among the main role-players is a prerequisite. Gerritsen (2009:99) argues that "tension, trust [and] power" are some of the words associated with the relationship between the Vice-Chancellor and Chair of Council, and quotes the Association of Universities and Colleges of Canada chair, Tom Traves:

The university president is the linchpin in this trusting relationship insofar as she or he requires the confidence of faculty, staff and students of the university to exercise presidential powers that are often based on a kind of moral authority, and, at the same time, the president requires the trust of the university's board, that she or he is carrying out essential duties in an effective manner.

Fourthly, communication seems to be a prerequisite for trust to be created and strengthened. Bess (2006) argues that uncertainty thrives in a culture of limited communication, especially among different, often opposing, political groups. Information that is exchanged should be "modulated by a belief in each other's competence and trustworthiness" (Bess 2006:532). The different actors in institutional governance must take time to consider their modes of communication - not only to clarify meaning, but also to assure counterparts of their sincerity and of the validity of their perspectives.

'Good' university governance does not simply happen. It is the product of informed, selfless and concerted efforts of all actors. "Ultimately, governance models are created by people to govern people. They are only as good as they who devise and apply them, as well as those who live by them" (Trakman 2008:77).

\section{REFERENCES}

Atwell RH. 1996. Higher education governance in despair. Journal for Higher Education Management, 11 (2).

Balderston FE. 1995. Managing today's university. Strategies for viability, change and excellence. San Francisco: Jossey-Bass Publishers.

Baldridge JV, Curtis DV, Ecker GP \& Riley GL. 1986. Alternative models of governance in higher education. In: MW Peterson (ed). ASHE Reader on organization and governance in higher education. Lexington: Ginn Press. 


\section{PART FIVE • STRUCTURES AND GOVERNANCE}

Barnett R. 2000. Realizing the university in an age of supercomplexity. Buckingham: Society for Research into Higher Education \& Open University Press.

Bess JL. 2006. Toward strategic ambiguity: Antidote to managerialism in governance. In: JC Smart (ed). Higher Education: Handbook of Theory and Research Volume XXI. Dordrecht: Springer.

Binsbergen P, De Boer H \& Van Vught F. 1994. Comparing governance structures of higher education institutions: Towards a conceptual framework. In: L Goedegebuure \& F van Vught (eds). Comparative policy studies in higher education. Utrecht: Center for Higher Education Policy Studies.

Birnbaum R. 1988. How colleges work. London: Jossey-Bass.

CHET (Centre for Higher Education Transformation). 2000. Leadership and institutional change in higher education. Pretoria: CHET.

Coldwell D. 2008. Mail \& Guardian Online. 27 November.

Corson J. 1976. Changes in the governance of institutions of postsecondary education. Changing patterns of governance in higher education. Tuscon: University of Arizona. (ERIC report).

Coughlan FJ. 2006. Bridging the divide: Managed managerialism. South African Journal of Higher Education, 20(5):582-591.

Frederiks M, Westerheiiden D \& Weusthof P. 1994. Stakeholders in quality. Improvement or accountability in five quality assessment systems in higher education. In: L Goedegebuure \& F van Vught (eds). Comparative policy studies in higher education. Utrecht: Centre for Higher Education Policy Studies.

Gerritsen J. 2009. Balancing the governance-management seesaw. In: A global view of the key issues confronting higher education. University World News.

Green MF and Hayward FM. 1998. Toward a new leadership model. In: MF Green (ed). Leaders for a new era. Strategies for higher education. New York: Macmillan.

Hardy C. 1990. Putting power into university governance. In: JC Smart (ed). Higher education: Handbook of theory and research. Vol. VI. New York: Agathon Press.

Harman K \& Treadgold E. 2007. Changing patterns of governance for Australian universities. Higher Education Research and Development, 26(1):13-29.

Hartman N \& Scott I. 1990. Introduction. In: N Hartman \& I Scott (eds). Restructuring South African tertiary education: Academic contributions to the debate on rationalisation. Johannesburg: UDUSA.

Johnson B. 2006. South African academia in crisis: the spread of 'contrived collegial managerialism'. South African Journal of Higher Education, 20(1):60-73.

Kaplan GE. 2006. Institutions of academic governance and institutional theory: A framework for further research. In: JC Smart (ed). Higher Education: Handbook of theory and research. Vol. XXI. Dordrecht: Springer.

Kauffman JF. 1993. Governing boards. In: A Levine (ed). Higher learning in America 1980-2000. Baltimore: The John Hopkins University Press. 
Lockwood, G. 1985. Governance. In: G Lockwood \& J Davies (eds). Universities: The management challenge. Windsor: The NFER-NELSON Publishing Company \& SRHE.

Mail \& Guardian, 13-16 March 2009.

Peterson, MW. 1986. Introduction. In: MW Peterson (ed). ASHE Reader on Organization and Governance in Higher Education. Lexington: Ginn Press.

Rhoades G. 1992. Governance: Models. In: BR Clark \& GR Neave (eds). The Encyclopedia of Higher Education. Vol. 2: Analytical perspectives. Oxford: Pergamon Press.

Talburt S. 2005. Ideas of a university, faculty governance, and governmentality. In: JC Smart (ed). Higher Education: Handbook of Theory and Research Volume XX. Dordrecht: Springer.

Tapper T \& Palfreyman D. 1998. Continuity and change in the collegial tradition. Higher Education Quarterly, 52(2): 142-161.

Trakman L. 2008. Modelling university governance. Higher Education Quarterly, $62(1 / 2): 63-83$.

Wolhuter CC, Higgs L \& Higgs P. 2007. South Africa: Rapid change and re-integration with the global community. In: W Locke \& U Teichler (eds). The changing conditions for Academic Work and Careers in Select Countries. Kassel: INCHER, University of Kassel. 